\title{
PENGEMBANGAN LEMBAR KERJA PESERTA DIDIK (LKPD) FISIKA BERBASIS ETNOSAINS MENGGUNAKAN MODEL DISCOVERY LEARNING UNTUK MENINGKATKAN KETERAMPILAN BERPIKIR KRITIS SISWA SMA
}

\author{
Liza Septia Ahmad*, Indra Sakti, Iwan Setiawan \\ Program Studi Pendidikan Fisika, Fakultas Keguruan dan Ilmu Pendidikan, Universitas Bengkulu, \\ Jl. W.R Supratman Kandang Limun, Bengkulu \\ Email : $\underline{\text { lizaseptiaahmad3@gmail.com }}$
}

\begin{tabular}{c|c|c|c}
\hline Diterima 17 Juli 2020 & Direvisi 3 Agustus 2020 & Disetujui 20 Agustus 2020 & Dipublikasikan 30 Agustus 2020 \\
\hline \multicolumn{4}{c}{ https://doi.org/10.33369/jkf.3.2.121-130 } \\
\hline
\end{tabular}

\begin{abstract}
ABSTRAK
Penelitian ini bertujuan untuk mengembangkan Lembar Kerja Peserta Didik (LKPD) fisika yang valid berbasis etnosains dengan model Discovery Learning untuk meningkatkan keterampilan berpikir kritis siswa SMA. Penelitian ini merupakan jenis penelitian pengembangan (Research and Development) dengan tipe rancangan level 1 yang terdiri dari 5 tahapan, yaitu: 1) potensi dan masalah 2) studi literatur dan pengumpulan informasi 3) desain produk 4) validasi desain 5) desain teruji. Validasi desain dilakukan oleh 2 judgement ahli dan 2 praktisi untuk menilai produk yang dikembangkan dari aspek penyajian, kelayakan isi, penggunaan bahasa, dan kegrafisan. Berdasarkan hasil uji validitas aspek penyajian didapatkan hasil persentase sebesar $82,8 \%$ berada pada kategori sangat baik, aspek kelayakan isi sebesar $80,9 \%$ berada pada kategori sangat baik, aspek penggunaan bahasa sebesar $92 \%$ berada pada kategori sangat baik, dan aspek kegrafisan sebesar $97,9 \%$ berada pada kategori sangat baik. Berdasarkan hasil tersebut, dapat disimpulkan bahwa LKPD fisika berbasis etnosains dengan model Discovery Learning yang dikembangkan sudah valid dan merupakan desain teruji dengan persentase total uji validitas yaitu $88,4 \%$ berada pada kategori sangat baik.
\end{abstract}

Kata Kunci: LKPD, Etnosains, Discovery Learning , keterampilan Berpikir Kritis

\begin{abstract}
This research aimed to develop a valid physical student activity sheets, LKPD based of ethnoscience with a Discovery Learning model on material and unit. This research was a type of development research (Research and Development) with type 1 design consisting of 5 stages, namely: 1) potential and problems 2) literature study and information gathering 3) product design 4) design validation 5) tested design. Design validation was carried out by 2 expert judgments and 2 Practitioners to assess products developed from aspects of presentation, appropriateness of content, use of language, and graphics. Based on the results of the validity of the presentation aspects, the results were $82,8 \%$ was in excellent categories, appropriateness of content aspects at $80,9 \%$ was in excellent categories, , use of language aspects at $92 \%$ was in excellent categories, and graphics aspects at $97.9 \%$ was in excellent categories. Based on these results, it was concluded that LKPD based of ethnoscience with a Discovery Learning model has been valid and is a proven design with a percentage of the total validity test which is $88,4 \%$ was in the excellent category.
\end{abstract}

Keywords: LKPD, Ethnoscience, Discovery Learning, Critical Thinking Skills

\section{PENDAHULUAN}

Perkembangan pendidikan sains sangat dipengaruhi dan didorong oleh perkembangan ilmu pengetahuan dan teknologi. Kemajuan perkembangan ilmu pengetahuan dan teknologi pada abad 21 ditandai dengan perkembangan kemampuan berpikir manusia dalam segala segi kehidupan, termasuk dalam proses pembelajaran. Kurikulum 2013 adalah kurikulum yang berlaku di Indonesia saat ini.

Berdasarkan hasil observasi yang telah dilakukan di SMA Negeri 7 Kota Bengkulu pada mata pelajaran fisika diketahui bahwa: 1) proses pembelajaran yang berlangsung masih dominan 
menggunakan metode ceramah sehingga guru yang terlibat aktif sedangkan siswa hanya mendengar penjelasan guru fisika di kelas, 2) penyampaian materi juga terkesan monoton, 3) guru hanya menjelaskan materi pada buku panduan tanpa adanya pengembangan materi, 4) bahan ajar yang digunakan guru dan siswa berupa buku cetak dan jarang sekali menggunakan LKPD, sehingga siswa tidak terlalu antusias dalam mengikuti proses pembelajaran, 5) kemampuan komunikasi siswa baik lisan maupun tulisan masih sangat terbatas, 6) siswa belum mampu mendefinisikan konsep, keterlibatan siswa dalam proses pembelajaran tidak terlihat secara mencolok, padahal guru sudah berusaha untuk mengadakan proses pembelajaran akan tetapi belum berjalan sebagaimana mestinya, 7) Keterampilan proses sains dalam bekerja tidak nampak secara jelas berkembang, dan 8) guru juga belum menekankan makna sains di dalam budaya dan mitos yang berkembang di masyarakat sehingga siswa kesulitan dalam mengaitkan materi pembelajaran dengan mitos yang sudah menjadi budaya yang berkembang di masyarakat.

Salah satu cara yang dapat dilakukan untuk meningkatkan kualitas proses pembelajaran adalah dengan menggunakan aspek budaya lokal dalam pembelajaran (1). Penggalian khusus mengenai pengetahuan asli di suatu masyarakat menjadi semakin penting untuk dikaji dalam sains yang dipelajari di sekolah. Hal ini secara umum disebut etnosains. Etnosains merupakan kegiatan mentransformasikan antara sains asli yang terdiri atas seluruh pengetahuan tentang fakta masyarakat yang berasal dari kepercayaan turun-temurun dan masih mengandung mitos yang meliputi bidang sains, pertanian, ekologi, obat-obatan, bahkan termasuk dari flora dan fauna (2). Lahirnya etnosains tidak terlepas dari pengetahuan yang ditemukan secara trial and error dan belum adanya kemampuan untuk menerjemahkan hasil temuannya ke dalam pengetahuan ilmiah (3). Pembelajaran berbasis etnosains bertujuan untuk memperkenalkan siswa mengenai fakta yang telah berkembang di suatu masyarakat yang kemudian dikaitkan dengan materi pembelajaran. Kegiatan pembelajaran berbasis etnosains merupakan pembelajaran yang dapat merancang pengalaman siswa serta Salah satu tradisi yang berkembang dalam masyarakat adalah menyatakan satuan ukuran beberapa besaran. Kebanyakan satuan ukuran tradisional ini dinyatakan dengan menggunakan bagian-bagian tubuh karena dianggap praktis dan dapat digunakan di lingkungan masyarakat. Satuan ukuran juga dijadikan sebagai alat untuk menyatakan ukuran dalam kegiatan transaksi jual beli atau pinjam meminjam.

Pembelajaran etnosains bertujuan untuk memperkenalkan siswa mengenai fakta yang telah berkembang di masyarakat, kemudian dikaitkan dengan materi-materi sains ilmiah dan pengetahuan (4). Penerapan pembelajaran ini berpotensi mengembangkan cara pembelajaran yang secara umum masih berpusat pada guru (teacher centered learning) menjadi berpusat pada siswa (student centered learning). Dengan demikian mampu meningkatkan apresiasi siswa terhadap budaya dan menciptakan suasana pembelajaran yang kontekstual dan penuh makna (5).

Pembelajaran fisika merupakan proses pembelajaran yang melibatkan siswa dalam mempelajari alam dan gejalanya melalui serangkaian proses ilmiah yang dibangun atas dasar sikap ilmiah untuk memperoleh dan memproses pengetahuan, keterampilan, dan sikap agar dapat mencapai tujuan belajar tertentu (6). Dalam proses pembelajaran fisika, siswa tidak hanya sekedar menghafal teori dan rumus, akan tetapi lebih ditekankan pada terbentuknya proses pengetahuan dan pemahaman konsep. Pemahaman konsep berkaitan erat dengan keterampilan berpikir kritis. Berpikir kritis merupakan suatu keterampilan untuk melakukan suatu pemeriksaan pengetahuan atau hal-hal yang dipercayai berdasarkan bukti-bukti pendukung. Melalui berpikir kritis, siswa akan dilatih untuk mengamati keadaan, memunculkan pertanyaan, merumuskan hipotesis, melakukan observasi, mengumpulkan data, dan memberikan kesimpulan (7).

Dalam pembelajaran diperlukan suatu inovasi model pembelajaran yang berpusat pada siswa dengan melibatkan peran aktif siswa dan dapat memberi kesempatan membangun pengetahuan. Salah satunya dengan menerapkan model pembelajaran berbasis konstruktivisme yaitu model Discovery Learning (8). Discovery Learning merupakan salah satu model pembelajaran yang memungkinkan siswa terlibat langsung dalam proses pembelajaran dan siswa menggunakan proses menemukan fakta-fakta dari sumber-sumber yang ada dan menyimpulkannya dari suatu permasalahan yang sudah dirancang.

Pengembangan Lembar Kerja Peserta Didik (LKPD) Fisika Berbasis Etnosains Menggunakan Model Discovery Learning untuk....

Liza Septia Ahmad, Indra Sakti, Iwan Setiawan 
Media pembelajaran seperti LKPD dapat membantu siswa dalam memahami konsep tertentu dan pembelajaran tidak berpusat pada guru tetapi berpusat pada siswa. Seorang guru dapat membekali siswa agar memperoleh keterampilan hidup (life skill) melalui pengembangan LKPD (lembar kerja peserta didik) (9).

Lembar Kerja Peserta Didik Berbasis Etnosains dengan Model Penalaran Klausal untuk Memecahkan Masalah telah dikembangkan dengan hasil berupa peningkatan kemampuan siswa dalam memecahkan masalah (10). Namun, LKPD yang dibuat berbasis etnosains menggunakan model Discovery Learning dengan indikator kemampuan berpikir kritis belum dikembangkan.

Oleh karena itu, perlu dilakukannya penelitian yang berjudul "Pengembangan Lembar Kerja Peserta Didik (LKPD) Berbasis Etnosains Menggunakan Model Discovery Learning untuk Meningkatkan Keterampilan Berpikir Kritis Siswa SMA”. Adapun rumusan masalah dalam penelitian ini adalah bagaimana mengembangkan LKPD yang valid berbasis etnosains menggunakan model Discovery Learning untuk meningkatkan keterampilan berpikir kritis siswa SMA.

\section{METODE PENELITIAN}

Metode yang digunakan dalam penelitian ini adalah metode Research and Development (R\&D). Metode R\&D (Research and Development) adalah metode penelitian yang digunakan untuk menghasilkan produk tertentu dan menguji keefektifan produk tersebut (11). Komponen LKPD yang dikembangkan dalam penelitian ini adalah LKPD Fisika Berbasis Etnosains Menggunakan Model Discovery Learning untuk Meningkatkan Keterampilan Berpikir Kritis Siswa SMA.

Metode yang digunakan adalah R\&D tipe rancangan level 1 yang terdiri dari potensi dan masalah, studi literatur dan pengumpulan informasi, desain produk, validasi desain, dan desain teruji (12). Penjelasan lebih lanjut mengenai langkah-langkah penelitian research and development dapat dilihat pada Gambar 1.

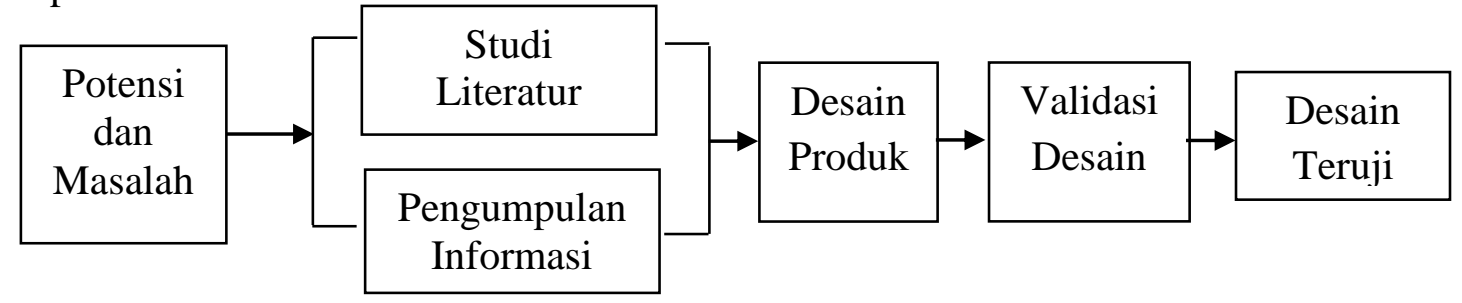

Gambar 1. Langkah-langkah Penelitian R\&D Level 1

Teknik pengumpulan data pada penelitian pengembangan level 1 dilakukan tiga kali yaitu pada tahap menentukan potensi dan masalah, pengumpulan informasi dan validasi desain. Teknik pengumpulan data pada tahap penelitian (research) ini adalah dengan angket dan observasi. Observasi dilakukan dengan menggunakan lembar observasi yang dilakukan di SMA Negeri 7 Kota Bengkulu. Angket digunakan sebagai alat untuk mengetahui tentang ketepatan dan kelayakan komponen LKPD fisika berbasis etnosains yang dikembangkan pada materi besaran dan satuan. Responden yang akan dilibatkan dalam pengambilan data ini adalah validator. Angket untuk validator dalam bentuk skala Likert, validator tidak akan menjawab salah satu jawaban kualitatif yang telah disediakan, tetapi menjawab salah satu jawaban kuantitatif yang telah disediakan. Angket validator menggunakan empat pilihan jawaban seperti yang tertera pada Tabel 1.

\begin{tabular}{cc} 
Tabel 1. Kriteria Penilaian Angket Validator \\
\hline Nilai & Pernyataan \\
\hline 1 & Tidak Baik \\
2 & Cukup \\
3 & Baik \\
4 & Sangat Baik \\
\hline
\end{tabular}

Instrumen yang digunakan dalam penelitian ini adalah 1) Lembar Observasi. Lembar observasi digunakan untuk mengidentifikasi potensi dan masalah dalam menganalisis kebutuhan terkait pengembangan LKPD fisika berbasis etnosains dengan model Discovery Learning pada pembelajaran Fisika kelas X SMA pada materi besaran dan satuan; 2) Lembar Pengumpulan 
Informasi. Lembar pengumpulan informasi digunakan untuk mengumpulkan informasi lebih lanjut tentang pengembangan LKPD digunakan ; dan 3) Lembar Validasi. Instrumen ini berbentuk angket yang berfungsi untuk memberi penilaian terkait pengembangan LKPD fisika berbasis etnosains dengan model Discovery Learning pada pembelajaran Fisika kelas X SMA.

Menggunakan analisis statistik deskriptif, data penelitian dapat dianalisis yaitu analisis data validasi ahli dan praktisi. LKPD dianalisis dengan mempertimbangkan masukan dan saran dari validator. Aspek-aspek yang diperhatikan dalam uji validasi yaitu aspek 1) penyajian; 2) kelayakan isi; 3) penggunaan bahasa; dan 4) kegrafisan.

Uji validasi yaitu dengan menghitung skor penilaian dari masing-masing komponen dengan pilihan jawaban sesuai dengan kriteria. Kriteria penskoran yang diberikan pada lembar validasi penilaian LKPD adalah rentang skor 1, 2, 3, dan 4. Masing-masing skor pada setiap butir penilaian telah diberikan rubrik untuk dapat memilih skor antara 1 sampai dengan 4. Menghitung nilai keseluruhan dengan rumus:

$$
P=\frac{n}{N} \times 100 \%
$$

dengan $P$ adalah persentase kelayakan, $n$ adalah jumlah skor rata-rata aspek penilaian dan $N$ adalah jumlah skor maksimal aspek penilaian. Teknik statistik yang digunakan untuk analisis deskriptif mengubah data menjadi ringkas dengan menggunakan kode. Data yang telah dibuat menjadi kode dipindahkan kedalam media yang mudah diolah berupa tabel distribusi frekuensi kelompok. Kriteria penilaian skor rata-rata dan presentase (13) dapat dilihat pada Tabel 2.

Tabel 2. Kriteria Interpretasi Skor

\begin{tabular}{cc}
\hline Persentase (\%) & Kriteria \\
\hline$\leq 25$ & Sangat kurang \\
$26-50$ & Kurang \\
$51-75$ & Baik \\
$76-100$ & Sangat Baik
\end{tabular}

LKPD yang dikembangkan dapat dikatakan valid/baik/layak apabila memenuhi kriteria kelayakan isi dengan persentase $\geq 51 \%$ (14).

Tahap-tahap pengembangan LKPD tersebut diuraikan sebagai berikut:

2.1 Potensi dan Masalah.

Untuk menemukan potensi atau masalah yang betul-betul masalah digunakan penelitian. Data tentang potensi dan masalah tidak harus dicari sendiri, tetapi bisa berdasarkan laporan penelitian orang lain, atau dokumentasi laporan kegiatan dari perorangan atau instansi tertentu yang masih $u p$ to date (11). Untuk mengetahui potensi dan masalah pada penelitian ini dilakukan dengan lembar observasi yang dilakukan di SMAN 7 Kota Bengkulu. Hal yang difokuskan yaitu tentang Kurikulum yang digunakan, bahan ajar yang digunakan guru dalam mengajar, metode yang digunakan guru dalam mengajar, serta antusias siswa dalam mengikuti pelajaran fisika khususnya di kelas X IPA.

2.2 Studi literatur dan pengumpulan informasi.

Studi literatur dilakukan untuk menemukan pendukung pelaksanaan penelitian ini yaitu dengan mencari informasi melalui jurnal, buku, dan internet untuk mengetahui penelitian yang menunjang pada penelitian dan pengembangan. Untuk mengumpulkan informasi lebih lanjut tentang pengembangan LKPD digunakan lembar pengumpulan informasi yang disebar ke 3 SMA di Kota Bengkulu yaitu SMAN 2 Kota Bengkulu, SMAN 7 Kota Bengkulu, dan SMAN 9 Kota Bengkulu, yang ditujukan untuk guru fisika dan siswa kelas X IPA.

2.3 Desain produk.

Untuk mendesain produk berupa LKPD fisika berbasis etnosains dengan model Discovery Learning pada materi Besaran dan Satuan di SMA dilakukan dengan tahapan yaitu mendesain materi dan mendesain LKPD. Penyusunan materi LKPD diawali dengan silabus, RPP, dan kompetensi dasar. Berdasarkan silabus, kompetensi dasar pada materi Besaran dan Satuan yaitu : (3.1) Menerapkan prinsip-prinsip pengukuran besaran fisis, ketepatan, ketelitian, dan angka penting, 
serta notasi ilmiah; (4.1) Menyajikan hasil pengukuran besaran fisis beserta ketelitiannya dengan menggunakan peralatan dan teknik yang tepat serta mengikuti kaidah angka penting untuk suatu penyelidikan ilmiah. Materi yang didesain dikutip dari beberapa referensi yang berisikan tentang materi besaran dan satuan berbasis etnosains. Penyusunan LKPD dimulai dari mendesain atau membuat kerangka LKPD yang akan dikembangkan. Berdasarkan kerangka awal desain LKPD berbasis etnosains dengan model Discovery Learning dalam kerangka LKPD dan materi yang digunakan yaitu materi besaran dan satuan. Setelah desain produk dibuat maka pembuatan produk awal untuk divalidasi bisa dikembangkan. Produk awal LKPD fisika materi besaran dan satuan berbasis etnosains dengan model disccovery learning yaitu cover, kompetensi yang akan dicapai, materi berupa pengetahuan fakta dan konsep yang berbasis etnosains dengan model disccovery learning dengan indikator keterampilan berpikir kritis, contoh soal disetiap sub bab yang dibahas dan terdapat latihan yang berbasis etnosains, evaluasi, dan daftar pustaka.

\subsection{Validasi desain}

Validasi desain merupakan tahap penilaian judgement ahli. Tahap ini dilakukan untuk mengetahui kevalidan desain LKPD fisika berbasis etnosains dengan model Discovery Learning yang dikembangkan. Terdapat 4 penilaian yaitu aspek penyajian, kelayakan isi, penggunaan bahasa, dan kegrafisan.

\subsection{Desain teruji}

Revisi produk digunakan untuk menyempurnakan berbagai kekurangan yang terdapat pada LKPD fisika materi besaran dan satuan berbasis etnosains dengan model Discovery Learning setelah mendapatkan saran dan masukan dari validator ahli dan praktisi, kemudian memperbaiki produk sesuai saran dan masukan validator. Rancangan yang telah diperbaiki merupakan rancangan yang telah teruji (11). Dengan demikian, setelah LKPD fisika berbasis etnosains masyarakat Bengkulu dengan model Discovery Learning telah divalidasi oleh validator dan direvisi maka rancangan LKPD tersebut merupakan desain yang telah teruji.

\section{HASIL DAN PEMBAHASAN}

Pengembangan produk LKPD berbasis etnosains dengan model Discovery Learning untuk meningkatkan keterampilan berpikir kritis siswa yang valid menggunakan langkah-langkah penelitian R\&D dengan tipe rancangan level 1 yaitu potensi dan masalah, studi literatur dan pengumpulan informasi, desain produk, validasi desain, dan desain teruji.

\subsection{Potensi dan Masalah}

Potensi dan masalah dilakukan dengan lembar observasi di SMAN 7 Kota Bengkulu. Potensi yang ditemukan yaitu di sekolah tersebut telah menerapkan kurikukum 2013 yang menuntut siswa untuk aktif selama proses pembelajaran, sehingga guru harus menciptakan suasana belajar yang dapat membuat siswa melakukan aktivitas selama proses pembelajaran. Selama proses observasi ditemukan masalah yaitu siswa kurang antusias atau tertarik dalam mengikuti pembelajaran fisika dikarenakan proses pembelajaran yang membosankan dan hanya mendengar penjelasan materi dari guru, guru menggunakan metode konvensional sehingga siswa kurang berperan aktif di dalam kelas, siswa dan guru hanya menggunakan buku cetak yang ada di sekolah dan belum menggunakan bahan ajar tambahan. Setelah ditemukan masalah selanjutnya dilakukan studi literatur dan pengumpulan informasi.

\subsection{Studi Literatur dan Pengumpulan Informasi}

Studi literatur dilakukan untuk mengumpulkan pendukung untuk pengembangan produk. Oleh karena produk yang dikembangkan adalah LKPD besaran dan satuan berbasis etnosains dengan model Discovery Learning maka berdasarkan hasil studi literatur dengan diterapkannya kurikulum 2013 maka diharapkan adanya peningkatan kualitas siswa salah satunya dilakukan oleh guru yang berfokus pada peningkatan kualitas pembelajaran di kelas dengan cara melibatkan siswa secara aktif dalam proses pembelajaran. LKPD dapat dikembangkan sebagai media untuk belajar aktif dan dapat mengarahkan siswa memecahkan persoalan fisika melalui langkah-langkah pemecahan masalah. Berdasarkan penelitian yang relevan dapat disimpulkan bahwa LKPD fisika berbasis 
etnosains dengan model Discovery Learning dapat dikembangkan sebagai bahan belajar siswa dan dapat membuat siswa lebih aktif dalam proses pembelajaran.

Pengumpulan informasi analisis kebutuhan pada penelitian ini menggunakan lembar pengumpulan informasi guru dan siswa yang disebar kepada 3 orang guru dan 108 orang siswa. Berdasarkan hasil pengumpulan informasi dari guru diketahui bahwa guru masih menggunakan buku cetak ketika melakukan pembelajaran fisika yang disediakan oleh sekolah dan jarang menggunakan bahan ajar tambahan seperti LKPD serta guru juga membutuhkan bahan ajar lain selain yang sudah tersedia dan guru tertarik dengan LKPD fisika berbasis etnosains dengan model Discovery Learning. Berdasarkan hasil analisis pengumpulan informasi dari siswa diketahui bahwa siswa yang tertarik dengan fisika hanya 24 orang $(22,2 \%)$ sedangkan siswa yang lain tidak tertarik dengan fiiska karena beranggapan bahwa fisika merupakan mata pelajaran yang sulit, hal ini dikarenakan belum adanya bahan ajar tambahan dalam membantu proses belajar siswa. 86 orang $(79,6 \%)$ siswa mengalami kesulitan untuk belajar fisika dikarenakan proses pembelajaran yang masih konvensional dan sumber belajar yang kurang menarik. 90 orang $(83,3 \%)$ siswa masih menggunakan bahan ajar berupa buku cetak selama proses pembelajaran yang didapatkan dari sekolah. 62 orang $(57,4 \%)$ siswa beranggapan bahan ajar yang digunakan kurang memudahkan siswa dalam belajar karena isi/konten sumber belajar yaitu berupa buku cetak yang disediakan sekolah masih belum membantu dalam proses kegiatan pembelajaran, sehingga siswa membutuhkan bahan ajar lain dan tertarik dengan LKPD fisika berbasis etnosains dengan model Discovery Learning .

\subsection{Desain Produk}

Desain produk berupa LKPD besaran dan satuan berbasis etnosains dengan model Discovery Learning dilakukan dengan tahapan yaitu mendesain materi dan mendesain LKPD. Penyusunan materi LKPD diawali dengan silabus dan RPP. Materi yang didesain dikutip dari beberapa referensi yang berisikan tentang materi besaran dan satuan berbasis etnosains. Kerangka desain LKPD yang dikembangkan yaitu: halaman sampul, kata pengantar, daftar isi, petunjuk belajar, kompetensi dasar, indikator, tujuan pembelajaran, ringkasan materi, LKPD berbasis etnosains menggunakan sintak model Discovery Learning dan indikator berpikir kritis.

Tabel 3. Desain LKPD Besaran dan Satuan Berbasis Etnosains Menggunakan Model Discovery Learning

No. Tampilan $\quad$\begin{tabular}{c} 
Keterangan \\
\hline 1
\end{tabular}


No.

2

3

4
Tampilan

Keterangan

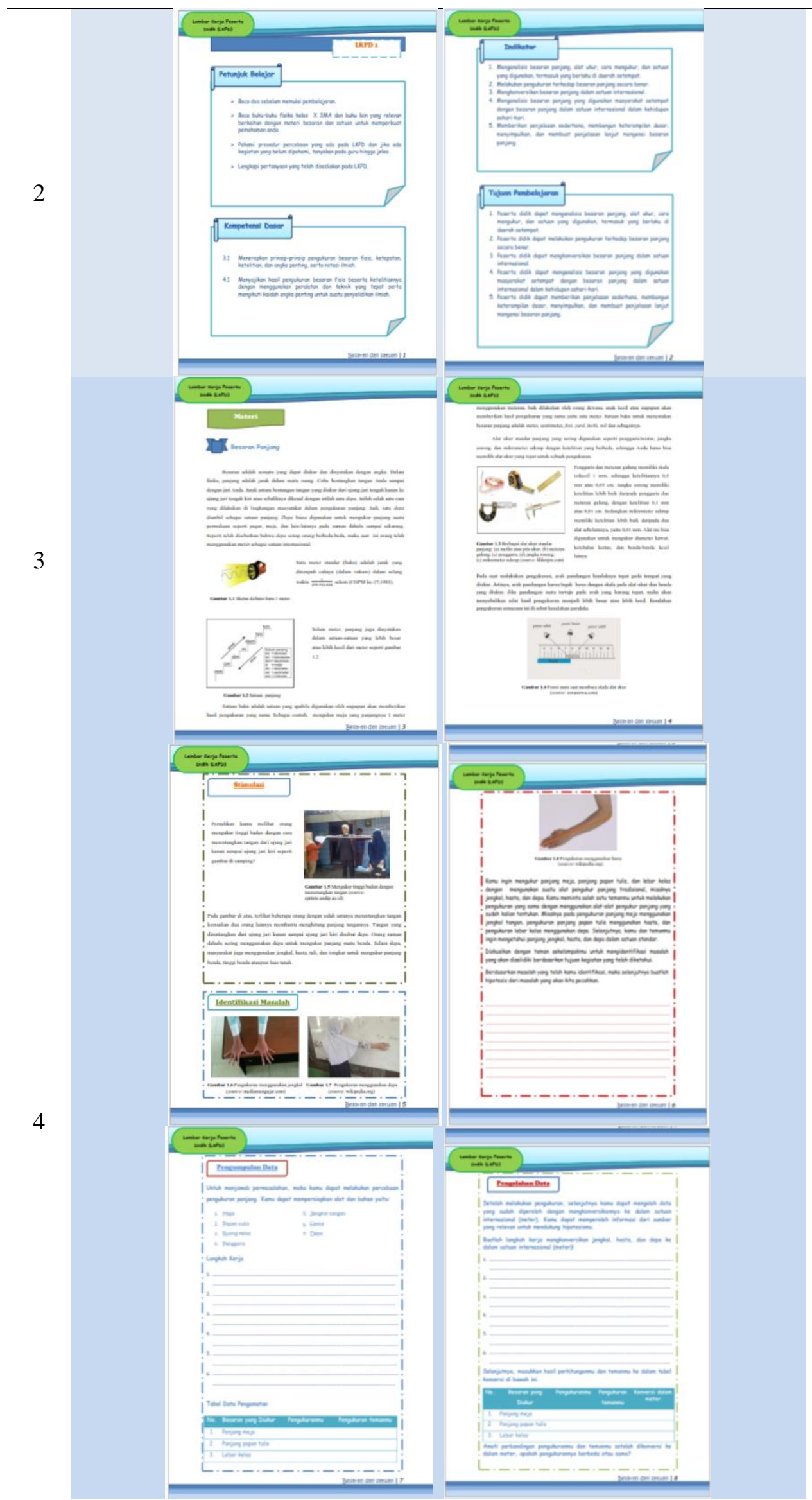

Tampilan petunjuk belajar, kompetensi dasar, indikator, dan tujuan pembelajaran

Tampilan ringkasan materi

Tampilan LKPD berbasis etnosains menggunakan model Discovery Learning dengan indikator keterampilan berpikir krritis 
No.

Tampilan

Keterangan

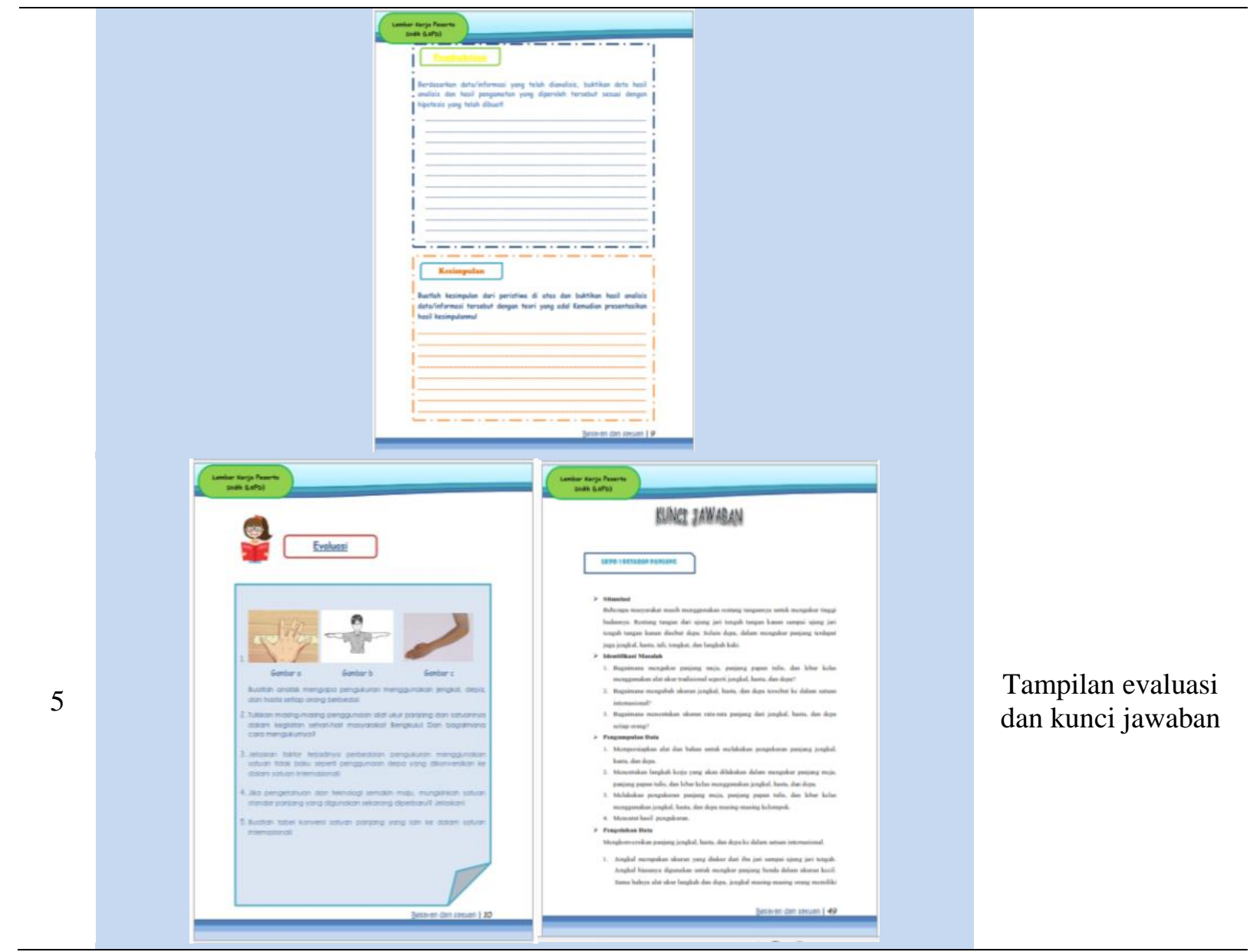

3.4 Validasi Desain

Uji validitas LKPD fisika berbasis etnosains dengan model Discovery Learning oleh ahli dan praktisi dapat dilihat pada Gambar 2.

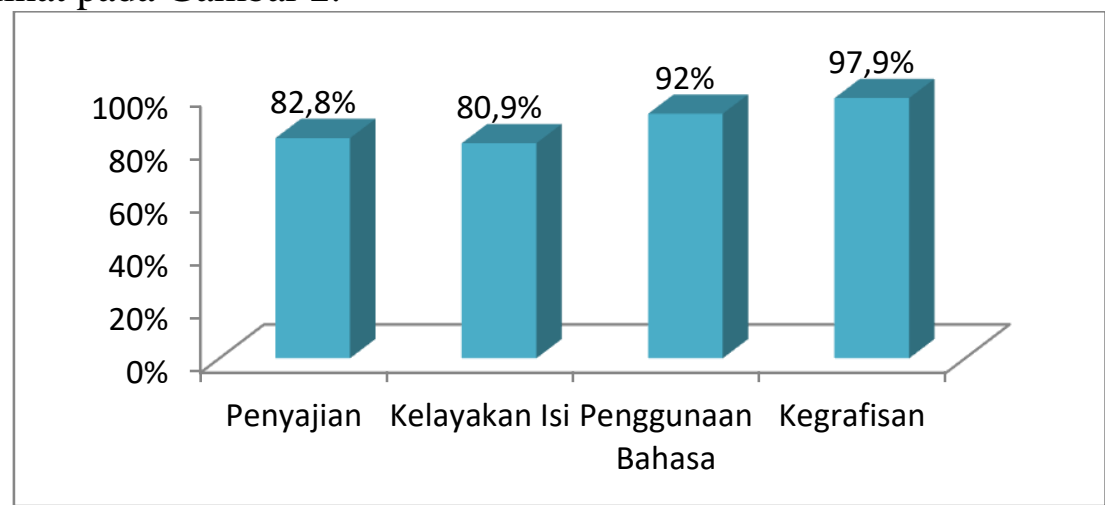

Gambar 2. Grafik hasil uji validitas

Gambar 2 menunjukkan LKPD fisika berbasis etnosains dengan model Discovery Learning yang sudah dikembangkan tergolong valid dalam kategori sangat baik dengan persentase rata-rata yaitu 88,4\% mengacu pada interpretasi skala likert pada Tabel 3 .

\subsection{Desain Teruji}

Masukan atau saran validator digunakan sebagai acuan untuk melakukan revisi. Revisi yang dilakukan yaitu aspek penyajian karena pada bagian tujuan pembelajaran belum mengakomodir etnosains dan indikator keterampilan berpikir kritis. Revisi juga dilakukan pada bagian halaman sampul karena belum bernuansa etnosains. Untuk aspek kelayakan isi, penggunaan bahasa dan kegrafisan tidak dilakukan revisi karena berdasarkan hasil uji validitas aspek kelayakan isi, penggunaan bahasa dan kegrafisan berada dalam kategori sangat baik. Sehingga, dapat disimpulkan 
bahwa LKPD fisika berbasis etnosains dengan model Discovery Learning yang sudah dikembangkan merupakan desain teruji.

Penelitian ini relevan dengan penelitian yang berjudul "Pengembangan Lembar Kerja Peserta Didik Berbasis Etnosains dengan Model Penalaran Klausal untuk Memecahkan Masalah", Hasil akhir dari penilaian validasi LKPD dari semua aspek memiliki kategori sangat baik. Berdasarkan hasil penelitiannya bahwa LKPD fisika berbasis etnosains dinyatakan telah valid dengan kategori sangat baik sehingga layak digunakan dalam proses pembelajaran(10). Penelitian yang berjudul "Implementasi Modul IPA Berbasis Etnosains Masyarakat Bengkulu untuk Meningkatkan Kemampuan Berpikir Kritis Mahasiswa di Program Studi Pendidikan IPA FKIP Universitas Bengkulu", hasil penelitiannya menunjukkan modul IPA yang berbasis etnosains dapat meningkatkan keterampilan berpikir kritis mahasiswa Pendidikan IPA FKIP Universitas Bengkulu (15). Kemudian penelitian yang berjudul "Ethno-Science Based LKPD Development on Material Substance and its Characteristics to Improve Learning Achievement of Junior High School Student", hasil penelitiannya menunjukkan LKPD berbasis etnosains yang digunakan menghasilkan peningkatan prestasi belajar siswa (16).

Saat melakukan pengembangan produk terdapat beberapa kendala. Kendala-kendala yang dihadapi saat mengembangkan LKPD fisika berbasis etnosains dengan model Discovery Learning adalah mendesain kegiatan pembelajaran menggunakan sintak Discovery Learning dengan indikator keterampilan berpikir kritis dan juga menentukan materi yang berbasis etnosains karena terbatasnya literatur yang ada. Adapun kelebihan produk akhir yang sudah dikembangkan dengan produk awal yang didapat yaitu LKPD yang dikembangkan menggunakan sintak Discovery Learning, berbasis etnosains, dan indikator keterampilan berpikir kritis.

\section{SIMPULAN DAN SARAN}

4.1 Simpulan

LKPD yang dikembangkan sudah valid dan merupakan desain teruji karena mendapatkan respon positif dengan presentase untuk aspek penyajian yaitu $82,8 \%$ berada pada kategori sangat baik, pada aspek kelayakan isi mendapat presentase $80,9 \%$ berada pada kategori sangat baik, pada aspek penggunaan bahasa mendapat presentase $92 \%$ berada pada kategori sangat baik, dan pada aspek kegrafisan mendapat presentase $97,9 \%$ berada pada kategori sangat baik. Rata-rata uji validitas dari aspek penyajian, kelayakan isi, penggunaan bahasa, dan kegrafisan adalah $88,4 \%$ berada pada kategori sangat baik.

\subsection{Saran}

Berdasarkan keterbatasan produk yang dikembangkan maka saran-saran untuk penelitian ini adalah: materi dalam LKPD yang dikembangkan hanya pada besaran panjang dan massa. Untuk pengembangan selanjutnya, materi berbasis etnosains dapat mencakup besaran lain. LKPD yang dibuat memiliki keterbatasan dalam penelitian yaitu belum diuji coba secara terbatas. Untuk pengembangan lanjutan, produk akhir dari penelitian ini dapat diuji secara eksternal dengan menggunakan metode penelitian research and development tipe rancangan level 2 (menguji tanpa meneliti).

\section{UCAPAN TERIMA KASIH}

Penulis mengucapkan terima kasih kepada dosen-dosen program studi Pendidikan Fisika FKIP Universitas Bengkulu, guru-guru fisika SMAN 7 Kota Bengkulu, dan semua pihak yang telah membantu dalam penelitian ini.

\section{DAFTAR PUSTAKA}
1. Indrawati M, Qosyim A, Sains KP. KEEFEKTIFAN LEMBAR KERJA SISWA ( LKS ) BERBASIS ETNOSAINS PADA MATERI. 2017;(2011).

2. Khoiri, Sunarno. Pendekatan etnosains dalam tinjauan fisafat. SPEKTRA. 2018;IV(02):145- 
53.

3. Ristanti AD, Rachmadiarti F. KELAYAKAN BUKU AJAR BERBASIS ETNOSAINS PADA MATERI PENCEMARAN LINGKUNGAN UNTUK MELATIHKAN BERPIKIR KRITIS SISWA SMP. J Pendidik Sains. 2018;1-5.

4. Rukayah, Sumarno, Subekti. Pengaruh Model PBL Berbasis Etnosains Pada Pembelajaran Tematik Subtema Pemanfaatan Kekayaan Alam Di Indonesia Terhadap Hasil Belajar Ranah Kognitif Siswa Kelas IV. In: Prosiding Seminar Nasional Sains dan Entrepreneurship V. 2018. p. 117.

5. Arfianawati S. MODEL PEMBELAJARAN KIMIA BERBASIS ETNOSAINS UNTUK MENINGKATKAN KEMAMPUAN BERPIKIR KRITIS SISWA. J Pengajaran MIPA. 2016;46-51.

6. Prasetyo, Wahyuni, Lesmono. Pengembangan Bahan Ajar IPA Berbasis Discovery Learning pada Pokok Bahasan Energi Kalor untuk Mengembangkan Kemampuan Berpikir Kritis Siswa SMP. In: Seminar Nasional Pendidikan Fisika. 2017.

7. Rhosalia LA. Pendekatan Saintifik (Scientific Approach) Dalam Pembelajaran Tematik Terpadu Kurikulum 2013 Versi 2016. JTIEE (Journal Teach Elem Educ. 2017;1(1):59.

8. Sari, Gunawan, Harjono. Penggunaan Discovery Learning Berbantuan Laboratorium Virtual pada Penguasaan Konsep Fisika Siswa. J Pendidik Fis dan Teknol. 2016;II(4):176-82.

9. Ubaidillah M. Pengembangan LKPD Fisika Berbasis Problem Solving untuk Meningkatkan Keterampilan Proses Sains dan Keterampilan Berpikir Tingkat Tinggi. J EduFisika. 2016;01(02):9-20.

10. Satriani, Rafiqah, Ikbal MS. PENGEMBANGAN LEMBAR KERJA PESERTA DIDIK BERBASIS ETNOSAINS DENGAN MODEL PENALARAN KAUSAL. J Pendidik Fis. 2018;6(1):8-16.

11. Sugiyono. Metode Penelitian dan Pengembangan. Bandung: Alfabeta; 2017.

12. Sugiyono. Metode Penelitian Pendidikan. Bandung: Alfabeta; 2010.

13. Rizal W. Pengembangan LKPD Matematika Berbasis Problem Based Learning untuk Meningkatkan Kemampuan Higher Order Thinking Skills Peserta Didik Kelas IV SD. 2018;300.

14. Septi, Sakti I, Putri DH. PENGEMBANGAN MODUL FISIKA DENGAN PEMBELAJARAN BERBASIS PROYEK PADA MATERI ALAT-ALAT OPTIK. J Kumparan Fis. 2019;2(3):129-36.

15. Sakti I, Nirwana. Implementasi Modul IPA Berbasis Etnosains Masyarakat Bengkulu untuk Meningkatkan Kemampuan Berpikir Kritis Mahasiswa di Program Studi Pendidikan IPA FKIP Universitas Bengkulu. Bengkulu; 2019.

16. Usman N, Rahmatan H, Aji AG. Ethno-Science Based Module Development on Material Substance and its Characteristics to Improve Learning Achievement of Junior High School Student. Int J Innov Sci Math. 2019;151. 